\title{
TEACHING WRITING DESCRIPTIVE TEXT THROUGH PICTURE WORD INDUCTIVE MODEL TO THE EIGHTH GRADE STUDENTS OF SMP MULIA PRATAMA
}

\author{
Arie Sartika Berutu, Novalina Sembiring, Jontra Jusat Pangaribuan \\ Catholic University of Saint Thomas
}

Email:novalina_sembiring@ust.ac.id

\begin{abstract}
Writing is an activity to share information in written form by combining some words into sentences and into paragraphs. Many students are still confused how to write a text because they do not know the rules and they can not express their ideas into written form. One of the strategies to teach writing is Picture Word Inductive Model (PWIM) whose its main activity is identifying and labelling all object and activities on the pictures. The method that is used in this research is Classroom Action Research (CAR). The subjects of this research are 25 students of Class VIII4 of Junior High School Mulia Pratama Medan in the Academic Year of 2017/2018. Test, observation sheets, field note and questionnaire were used as the instruments for collecting the data. The result of this study showed increasing score of the students' writing descriptive text. The result of the test showed that the students' mean score in pre-test is 35,6 with $0 \%$ of the students got score $\geq 75$, in formative test the mean score is 58,2 with $8 \%$ of the students got score $\geq 75$ and in post-test the mean score is 69,5 with $24 \%$ of students got score $\geq 75$. It showed that the percentage improvement of the students' mean score from pre-test to post-test was 24\%. The responses of students after being taught by using Picture Word Inductive Model are good. The students enjoyed the process of teaching and learning. It is suggested that teachers use Picture Word Inductive Model in teaching writing skill to improve the students' skill in writing descriptive texts.
\end{abstract}

Keywords: Picture Word Inductive Model (PWIM), Writing Descriptive Texts, Classroom Action Research (CAR)

\section{INTRODUCTION}

\subsection{The Background of Study}

English is one of the languages that is used by people to communicate in the world. In Indonesia, English has been taught as a foreign language. The purpose of learning English is to enable students to speak and write in English. In studying English, there are four skills that should be learnt by the students, namely are listening, speaking, writing and reading. These skills are categorized into receptive skills and productive skills. Listening and Reading skills are considered as receptive skills while speaking and writing skills are consider as productive skills.

Writing is an activity to share information in written form by combining some word into sentences and into paragraphs. The students of Junior High School learn about descriptive text, recount text, report text, procedure text, and narrative text.

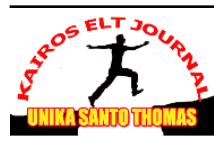


As written in the standard competence in the syllabus, the students in Junior High School are expected to be able to write simple paragraphs. Writing descriptive text is one of competences in Junior High School. There are some elements in writing descriptive texts that must be taught by the teachers and be noticed by students, namely communicative purpose, rhetorical structure and grammatical patterns. Communicative purpose in descriptive texts is to describe in general a specific/particular person, animal, or thing, rhetorical structure is about the construction of the text and grammatical patterns is the roles to make a good sentences.

Based on the writer's observation in SMP MULIA PRATAMA Medan students were confused to write a text because they did not know the grammar. For example, instead of writing "This is the students' book" they often write " This is the student book". Students were also still confused about what they would write and how to start to write even though they had some ideas in their mind. They could not express their ideas into written form and as the result they could not pass the minimum criteria mastery score of 75 in English subject.

Based on the explanation, the writer was interested in knowing the suitable strategy in teaching writing (henceforth, PWIM). In teaching English, there are many strategies that can be used to help students in writing process, but in this case writer uses Picture Word Inductive Model. This Model was chosen because the procedure of The Picture Word Inductive Model (PWIM) in teaching a descriptive text gives a good effect in student' ability in writing. According to Calhoun (1999:21) PWIM is an inquiry-oriented language arts strategy that uses pictures containing familiar objects and action to elicit words from children's listening and speaking vocabularies.

The PWIM is the combination between picture and word. Harmer (2004:67) states that music can stimulate creativity of students and also picture, picture is good to stimulate to written production. By giving the combination of picture and word to students, their creativity will be better. This combination can also stimulate students' ideas in writing.

Several studies have shown good results of applying PWIM in writing skill. The research has been done by Zuraida et al. (2012:10) entitled "Improving Student's Writing Descriptive Text by Using PWIM". The research finding that by using Picture Word Inductive Model the student can classify the words and makes sentences about the picture and try to think inductively. The research show in the first cycle the percentage of the student standard score was $78.1 \%$ then the second cycle significantly improve into $100 \%$. This strategy was also practical way for teaching and learning process to make writing easier and more effective in order to improve students ability in writing a descriptive text.

The second research has been done by Lina (2015) entitled " The Use of PWIM strategy to Improve Students' Writing Skill of Recount Text (An Action Research of the Eighth Graders of Junior High School 2 Semarang in the academic

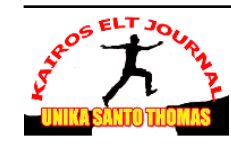


year of 2014/2015)". The students' average score in pre-test was 60.40 , in cycle 1 test was 75.63, and in post-test was 82.37 .

Based on the explanation and the findings of the previous researches the writer is interested in conducting a research related to teaching writing descriptive texts by using Picture Word Inductive Model to the eighth grade students of SMP MULIA PRATAMA Medan.

\section{REVIEW OF LITERATURE}

\subsection{Writing}

According to Harmer (2004: 79-80), writing is a basic language skill, as important as speaking, listening and reading. Students need to know how to write letters and put written reports together. Simply, writing is a skill that is used to give information through written form. Kane (2000: 2) states that there are two assumptions of writing. Writing is a rational and a valuable activity. Writing is rational means that it is an exercise of mind requiring the mastery of techniques anyone can learn. That writing is a valuable means indicates practical benefit in almost any job or career.

\subsubsection{The Components of Writing}

Heaton (1988:138) states that writing is complex and difficult to teach and requires mastery not only of grammatical and rhetorical devices, but also of conceptual elements. There are five components of writing as follows :

1) Content : the ability to think creatively and develop thoughts, including all of the relevance to assign the topic.

2) Organization : the ability to write appropriately for particular purpose with a particular audience in mind, together with an ability to select, and to organize relevant information.

3) Vocabulary : the ability to write the word effectively and appropriately.

4) Language use : the ability to use correctly those standard language, not the colloquial ones, e.g - is not instead of ain't, has not instead of hasn't, etc.

5) Mechanic : the ability to write spelling, punctuation, capitalization, paragraph and handwriting whether or not can be read.

Briefly, a writer needs to consider the five components of writing so that the content and purpose of a text can be understood by the readers.

\subsubsection{Writing Process}

According Harmer (2004:4) writing process is the stages a writer goes through in order to produce something in its final written form. Final written form is the product of writing such as essay, text, paragraph, report, etc. Furthermore, Carroll (1994:15) divides writing process into five parts, they are:

a. Prewriting, is the freely exploring topics, choosing a topic, and beginning to gather and organize details before you write.

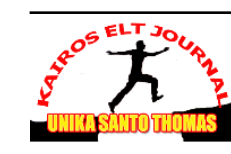


b. Drafting, is getting your ideas down on paper in roughly the format you intend

c. Revising, is correction any major errors and improving the writing's form and content.

d. Editing and proofreading, are polishing the writing and fixing errors in grammar, spelling, and mechanics.

e. Publishing and presenting are sharing your writing.

From the definition above, it can be concluded that writing process is activity when the writers write down about their feelings and ideas on the paper and the process have rules to make the activity of writing easier. And also the process of writing is need some steps that can be produce one good text that is first the writer should fine the idea and write all that out from the brain, after get the idea the writer may select the points that relate to the idea. Then the writer can start from draft , revise and edit the draft until it becomes a good paragraph of text.

\subsubsection{The Purpose of Writing}

Wong (2004:283) states that the goal of writing in school is to provide students with an opportunity for self-exploration. It means from writing students can explore their idea into the writing form. Meanwhile, Copeland (2011:13) mentions that there are some different types of the purpose of writing, i.e : to express; to describe; to explore/learn; to entertain; to inform; to explain; to argue; to persuade; to evaluate; to problem solve. The explanations of the ten types of writing purpose are elaborated as follows:

\section{To Express}

In expressive writing, the writer's purpose or goal is to put thoughts and feelings on the page. Expressive writing is personal writing. Usually expressive writing is informal just for own self to express the feeling.

\section{To Describe}

Descriptive writing describe people, places, things, moments and theories with enough vivid detail to help the reader create a mental picture of what is being written about. Description also make the readers to feel as the reader there are in experience of the writer.

\section{To Explore/Learn}

In exploratory writing, the writer's purpose is to ask key questions and reflect on topics that defy simple answers. In those topics where intuition and reflection are more important than rational analysis or argumentation, writers focus more on their journey of discovery than on any definite answers.

\section{To Entertain}

As a purpose or goal of writing, entertaining is often used with some other purpose - to explain, argue, or inform in a humorous way. Sometimes the writers write a text to entertain the reader from the stories or joke.

\section{To Inform}

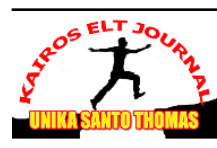


Writing to inform is one of the most common purposes of writing. Most journalistic writing fits this purpose. Writing to inform is done by a journalist. Other examples of writing to inform include laboratory reports, economic reports, and business reports.

\section{To Explain}

Writing to explain, or expository writing, is the most common of the writing purposes. Writing to explain has purpose to combine fact and information or knowledge and experience sometime to clarify for how is something happen.

\section{To Argue}

Argument is a specific type of persuasion that follows certain ground rules. Those rules are that opposing positions will be presented accurately and fairly, and that appeals to logic and reason will be the primary means of persuasion. An arguing essay attempts to convince its audience to believe or act in a certain way.

\section{To Persuade}

Although the terms argument and persuasion are often used interchangeably, the terms do have slightly different meanings.. Persuasive writing may, if it wishes, ignore those rules and try any strategy that might work. Advertisements are a good example of persuasive writing. They usually do not fairly represent the competing product, and they often appeal to image, to emotion, to character, or to anything except logic and the facts - unless those facts are in the product's favor.

\section{To Evaluate}

Writing to evaluate a person, product, thing, or policy is a frequent purpose for writing. An evaluation is really a specific kind of argument: it argues for the merits of the subject and presents evidence to support the claim. A claim of value - the thesis in an evaluation-must be supported by criteria (the appropriate standards of judgment) and supporting evidence (the facts, statistics, examples, or testimonials).

\section{To Solve Problems}

Problem solving is another specific type of argument: the writer's purpose is to persuade his audience to adopt a solution to a particular problem. Often called "policy" essays because they recommend the readers adopt a policy to resolve a problem, problem solving essays have two main components: a description of a serious problem and an argument for specific recommendations that will solve the problem. The thesis of a problem-solving essay becomes a claim of policy: If the audience follows the suggested recommendations, the problem will be reduced or eliminated. The essay must support the policy claim by persuading readers that the recommendations are feasible, cost-effective, efficient, relevant to the situation, and better than other possible alternative solutions.

Writing has some purpose in the human live and it depends on writer what the main of the text and for who the text. in this research the purpose of writing is to describe something.

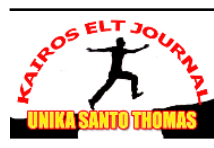




\subsection{The Genre of Text}

Genre is word for kind or class. genre used to be related to category of literary composition, such as novels, plays, short stories, poem, etc. the term is widely used in rhetoric, literary and in linguistics and also distinctive types of text. According to Hyland (2004:4) states that genre is a term for grouping texts together, representing how writers use language to respond to recurring situations. Gerrot and Wignell (1994:158) defines the genre of text to fourteen, they are :

1. Spoof is text to retell an event a humors twist.

2. Recount is text to retell events for the purpose of informing or entertaining.

3. Reports is text to describe the way things are, with reference to a range of natural, man-made and social phenomenon in our environment.

4. Analytical Exposition is text to persuade the reader or listener that something is the case.

5. News Item is text to inform readers, listeners or viewers about events of the day which are considered newsworthy or important.

6. Anecdote is text to share with others an account of an unusual or amusing incident.

7. Narrative is text to amuse, entertain and to deal with actual or vicarious experience in different way; Narrative deal with problematic events which lead to a crisis or turning point of some kind, which in turn finds a resolution.

8. Procedure is text to describe how something is accomplished through a sequence of action or step.

9. Hortatory Exposition is text to persuade the reader or listener that something should or should not be the case.

10. Explanation is text to explain the processes involved in the formation or working of natural or sociocultural phenomenon.

11. Discussion is text to present (at least) two points of view about an issue.

12. Reviews is text to critique an art work or event for a public audience such work of art include movies, TV shows, books, plays, operas, recordings, concert and ballets.

13. Commentary is text to explain the processes involved in the formation (evolution) of a sociocultural Phenomenon (Teddy Bear), as though a natural phenomenon. The text sends up the field of natural science, using the Explanation Genre to do so.

14. Description is text to describe a particular person, place or thing.

From explanation above the genre can be defined as class of text each text have the purpose and different characteristics. The writer choose descriptive text in this study because in junior high school students get descriptive text, report text, procedure text, recount text, narrative text, and news items.

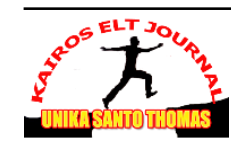




\subsection{Descriptive Text}

According to Gerrot and Wignell (1994: 208) descriptive text is text to describe a particular person, place or thing. Carroll et al. (2001:97) state description is writing that uses vivid details to capture a scene, setting, person, or moment. It means descriptive text is one of genre of text that tells about person, thing and place that related with scene, setting, or moment and also with use five sense.

\subsubsection{Types of Description}

From the definition of descriptive text that is to tell about something can be person, things or place. It make there are some types of description text. According to Carroll et al. (2001:97) there are five types of description :

1. Physical description that may focus on the appearance of a person, place or thing, as well as on its significant.

2. Description of idea use concrete images or analogies to help readers understand abstract or complicated concept.

3. Functional descriptions describe the component parts of a whole for partical purpose, such as fixing a bicycle.

4. Remembrance illustrate memorable parts of the writer's past by describing a person, place, thing, or event.

5. Character sketches illustrate the appearance and personality of a real or fictional character.

From explanation above descriptive text not only describe the real material but also something abstract such as idea, character and imagination.

\subsubsection{Parts of Descriptive Text}

According to Gerrot and Wignell (1994:208) in writing descriptive, there are several things that should be understood as the following:

1. Generic Structure

a. Identification (introduction) : is the part of paragraph that introduces the character.

b. Description : is the part of paragraph that describes the character.

2. Significant Lexicogrammatical Feature

a. Focus on specific participant

Specific participants is the subject of the story for example: I, My friend, My pet, animal, Eiffel Tower, etc.

b. Using Linking Verb

Linking verb is a verb that joins the subject of a sentence to the complement. For example is, are, feel, grow, look, prove, remain, smell, sound, taste, and turn.

c. Using adjective

Adjective that have the quality to describing, numbering and classifying for example: strong legs, sharp white

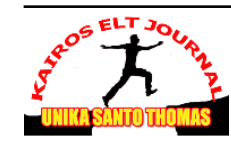


d. Using Adverb

Adverb is to give information about the object or adjective that explained, for example: very, extremely, quickly, definitely.

e. Using Simple Present Tense.

Simple present tense that is use to express activities, habits and also the fact of common about something. The formula is shown in the table.

\begin{tabular}{|l|l|}
\hline Formula & Example \\
\hline Subject + Verb1+ o/c & - I go to school \\
& - She goes to my office \\
& - He ha a pointed nose \\
\hline
\end{tabular}

\subsection{Picture Word Inductive Model}

According to Calhoun (1999:21), the Picture Word Inductive Model is an inquiry-oriented arts strategy that uses pictures containing familiar objects and actions to elicit words from children's listening and speaking vocabularies. PWIM is about teaching beginning reading and writing and this strategy uses an integrated language arts approach to teaching beginning reading and writing, and it includes the component skills of phonetic analysis, structural analysis, spelling, and mechanics. Teachers can apply this model as strategy in classes, small groups, and individuals to lead them into inquiring about words, discovering phonetics and structural principles, and using observation and analysis in their study. In general PWIM can improve language of students because teacher teach a student how to read a word and to write them.

Calhoun (1999:25) states that in PWIM strategy, the students are presented with pictures of sequenced pictures. Then, they shake out the words from the picture by identifying the objects, actions, and qualities they recognize in the picture. The teacher helps them to draw a line from the object to the surrounding board and writes the words or phrases. So, the students will dive in the words from pictures first before they get the writing section. Besides, Picture Word Inductive Model also builds on the listening and speaking vocabularies of the students.

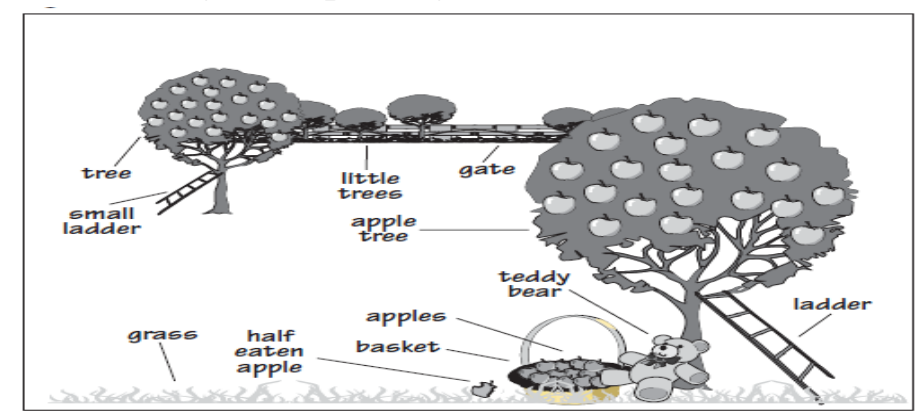

Figure 1. Labelled Picture in Picture Word Inductive Model

By using PWIM, the teacher is not only teaching writing but also teaching speaking, pronunciation, and listening. Those benefits are directed to the 
vocabulary improvement in which when the students know all of the objects in the pictures, they will generate the ideas and tell about the pictures easily.

\subsubsection{Procedures Teaching Descriptive Text through PWIM}

According to Calhoun (1999:23), in applying PWIM (Picture Word Inductive Model), there are some steps that must be followed. Those steps are modified based on the context and students' need. Those are:

1. Select a picture.

The picture should be related to the students' age and knowledge and also match with syllabus. Colhoun (1999:78-79) shares tips to selecting the picture as follows:

a. The richer the content of the picture, the more opportunities for students to develop and expand the words.

b. The large the picture is better.

c. Give enough space to write down the name of the objects in around the pictures.

d. Place the pictures at eye level for the student to aid their exploration

2. Ask students to identify what they see in the picture.

3. Label the picture parts identified. (Draw a line from the identified object or area, say the word, write the word; ask students to spell the word aloud and then to pronounce it.). some tips for labelling the picture are :

a. Write the words in large enough size so that student at distance from the pictures will be able to read them clearly.

b. If students give more one label in same object, write all labels.

4. Read and review the picture word chart aloud. The students can add the words and develop their ideas. The teacher spell aloud the words correctly and let the students hear the words pronounced correctly many times.

5. Lead students into creating a title for the picture word chart. Ask students to think about the information on the chart and what they want to say about it.

6. Ask students to generate all the word in the picture word chart into paragraph.

7. Read and review the sentences and paragraphs.

Simply, PWIM is a strategy that uses the combination of pictures and word as the main point of learning process. Later, the provided pictures will be identified by the students with the teacher guidance. The purpose of this activity is to know all the object in the picture so it help them to next writing section. After the word collected, the teacher can practice by reading all the word collected. This activity is very useful to improve students' pronunciation, spelling, listening, and speaking. It also help to improve students' vocabulary. After know and understand all the labels of pictures, the students begin to write descriptive text with the word chart as the guidance. 


\subsubsection{Strengths of the PWIM}

There are some strengths of Picture Word Inductive Model to students and teachers they are:

1. Students stimulated to thinking inductively

2. Student hear the words pronounced correctly many times so that students are not wrong to say the word.

3. Picture and words inductive in this model can guide the students develop their imagination and idea to make a sentences or paragraph. By using interesting pictures, the writing task will be more enjoyable.

4. The Picture Word Inductive Model provides concreate visual for the learning of new words, phrases, and sentences. This model give interesting visual in order to makes it easier for the students to learn new word, phrases, and also make sentences.

5. Because the students use the picture and labeling the picture together it makes all of students have participate in class activities.

6. The Picture Word Inductive Model can help the teacher to provide a better curricular and instructional balance by focusing lessons on composing and comprehending the subject.

7. In writing the sentences, the teacher uses standard English (transforming student sentences if necessary) and uses correct punctuation and mechanics (e.g., commas, capital letters). As different mechanical and grammatical devices are used, the teacher describes why the device is used. After several lessons and experience with the teacher modeling the devices, the students learn how to use them, too.

\section{RESEARCH METHODOLOGY}

\subsection{Research Design}

Research design is how the writer conducts the research. In this research the writer used classroom action research to found out how well Picture Word Inductive Model (PWIM) in teaching the eighth grade students of SMP MULIA PRATAMA Medan in academic year 2017/2018. The data of this study were quantitative and qualitative data. According to Burns (2010:2) action research is applied to identify a 'problematic' situation or issue that the participants - who may include teachers, students, managers, administrators, or even parents - consider worth looking into more deeply and systematically. Kemmis and McTaggart (in Burns, 2010:7) state that action research typically involves four phases in a cycle of research. The first cycle may become a continuing, or iterative, spiral of cycles which recur until the action has achieved a satisfactory outcome and researcher feels it is time to stop. Each cycle has three meetings. The next cycle is done to improve the action in previuos cycle.

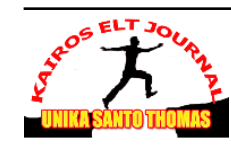




\subsection{The Location and Time of the Study}

This study conducted at SMP MULIA PRATAMA at Jl. Jahe Raya No.1. The reason for choosing this school was because the students at the school have problems with English subject specially in writing. In addition the school principal allows the writer to conduct a research at the school because there has never been a researcher who conducts a research by using Picture Word Inductive Model. This study conducted in August to September on Academic Year 2017/2018.

\subsection{The Subject of the Study}

The subject of this study was the eighth grade students of SMP MULIA PRATAMA Medan. There were four classes of eight grade students. The writer choose VIII-4 class as the subject of the study. There were 25 students. The female were 10 students and male were 15 students. The reason for choosing this class is because most of students in the class still get a bad mark in English subject especially in writing skill.

\subsection{Types of data}

There were two kinds of data of this research were collected through quantitative and qualitative data. The qualitative data is in the forms of the description of the process during action written in observation of teaching learning while the quantitative data is in the form of the students' writing score.

\subsection{The Procedure of the Research}

In this Classroom Action Research (CAR), the writer will do two cycles to collect the data and every cycle consist of three meetings which contain four phases based on Kemmis and Mctaggart (in Burn 2010:9).

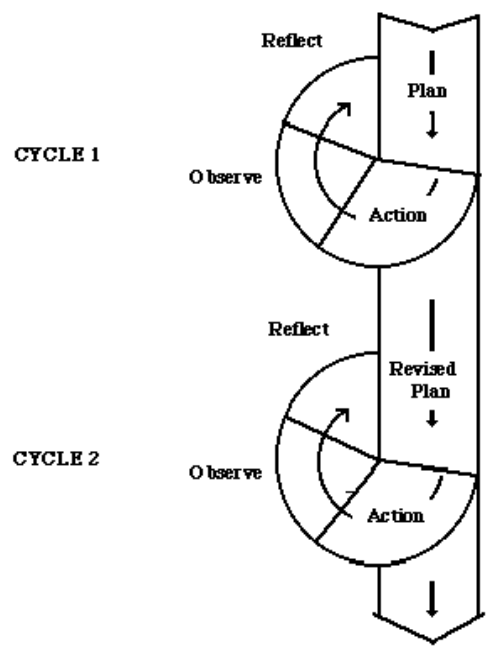

Figure 2. Figure Cyclical Classroom Action Research model Kemmis and Mc Taggart in Burns (2010:9) 


\subsection{Technique of Data Analys is}

The students' essay writing scored and analyzed using scoring technique from Weigle (2002:116). There are five components to be analyzed :content, organization, vocabulary, language usage, and mechanics. The analytical scoring rubric is explained follows:

Table 1. Scoring of Writing Skill

\begin{tabular}{|c|c|c|c|}
\hline No & $\begin{array}{l}\text { Components } \\
\text { of Writing }\end{array}$ & Scores & Indicators \\
\hline 1 & Content & $\begin{array}{l}4 \\
3 \\
2 \\
1\end{array}$ & $\begin{array}{l}\text { Relevant to the topic and easy to understand } \\
\text { rather relevant to the topic and easy to understand } \\
\text { relevant to the topic but is not quite easy to } \\
\text { understand } \\
\text { quite relevant to the topic but is not quite easy to } \\
\text { understand }\end{array}$ \\
\hline 2 & Organization & $\begin{array}{l}4 \\
3 \\
2 \\
1\end{array}$ & $\begin{array}{l}\text { most of the sentences are related to the main idea } \\
\text { some sentences are related to the main idea } \\
\text { few sentences related to the main idea } \\
\text { the sentences are unrelated to each other }\end{array}$ \\
\hline 3 & Vocabulary & $\begin{array}{l}4 \\
3 \\
2 \\
1\end{array}$ & $\begin{array}{l}\text { Good vocabulary } \\
\text { Some vocabulary miss } \\
\text { Poor expression and vocabulary } \\
\text { Inappropriate vocabulary }\end{array}$ \\
\hline 4 & $\begin{array}{l}\text { Grammar } \\
\text { (language } \\
\text { usage) }\end{array}$ & $\begin{array}{l}4 \\
3 \\
2 \\
1\end{array}$ & $\begin{array}{l}\text { a few grammatical inaccuracies } \\
\text { some grammatical inaccuracies } \\
\text { numerous grammatical inaccuracies } \\
\text { frequent grammatical inaccuracies }\end{array}$ \\
\hline 5 & Mechanic & $\begin{array}{l}4 \\
3 \\
2 \\
1\end{array}$ & $\begin{array}{l}\text { a few errors in choice of words, spelling and } \\
\text { punctuation } \\
\text { some errors in choice of words, spelling and } \\
\text { punctuation } \\
\text { occasional errors in choice of words, spelling and } \\
\text { punctuation } \\
\text { frequent errors in choice of words, spelling and } \\
\text { punctuation }\end{array}$ \\
\hline
\end{tabular}

Based on the writing assessment above, the maximum score could be achieved by students is 100 . The final score is obtained by summing up each category score.

The writer uses this following formula to calculate the final score :

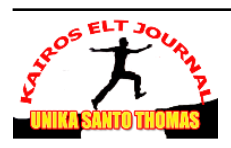


$\mathrm{X}=\Sigma \times 5$

Note:

$\mathrm{X}$ : Individual score

$\Sigma$ : Total score

After obtains all students' score in the classroom, the writer counts the average of students' writing score by using the formula as be follows:

$\bar{X}=\frac{\sum x i}{n}$

Note:

$\bar{X}:$ mean

xi : individual score

$\mathrm{n}$ : number of students

Next to know the class percentage which passed the minimum Mastery criterion- Kriteria Ketuntasan Minimal (KKM) 75, the writer uses the formula:

$$
p=\frac{F}{N} \times 100 \%
$$

Note:

$\mathrm{P}$ : the class percentage

$\mathrm{F}$ : total students who passed the KKM

$\mathrm{N}$ : number of students

After the average score, the writer compared the result of pre-test and posttest to know whether there was any improvement or not.

\section{DATA ANALYSIS AND DISCUSSION}

\subsection{Data Analysis}

The data in this study were collected by qualitative and quantitative data. The qualitative data were taken from observation sheet, field notes and questionnaire. The quantitative data were taken from the students' writing score which collected through pre-test, formative test and post-test in both of cycle. Every cycle was conducted in four meetings. Pre-test was done in the first meeting and formative test at the end of cycle I in the last meeting. The second cycle was also conducted in four meetings including post-test.

\subsection{Discussion}

Picture Word Inductive Model was applied to improve students' skill in writing descriptive text to VIII-4 at SMP MULIA PRATAMA. As the collaborator, the English teacher and the writer collaboratively discussed the result of the study. They concluded that use Picture Word Inductive Model could be the effective way to help students in writing the descriptive text. It was shown in histogram 4.4, in which the mean score of each test improved. The mean score of pre-test is 35,6 , formative test is 58,2 , and the post-test is 69.5 . Those scores showed that the second cycle was better than the first cycle.

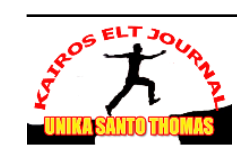


The improvement can be also seen from the percentage of students who got score $\geq 75$. In pre-test, there was $0 \%$ (no one students) Who got score $\geq 75$, in formative test, there are $2(8 \%)$ of students who got point $\geq 75$. And then, there are $6(24 \%)$ of students who got point $\geq 75$ in post test. However, there is about $24 \%$ students were got point $\leq 75$. Besides that, the improvement can be seen in the observation sheet, field notes, and questionnaires. Most of the students were more active and enthusiastic during the process of teaching and learning that started from the first to second cycle when the strategy was applied.

In conclusion, Picture Word Inductive Model is a suitable strategy to improve students' skill in writing descriptive text because this strategy gave students a chance to think inductively from a picture and can to describe something with see the picture first and explain about it. After that, students can be more active with they were mention all thing in the picture and it make them tried to express their idea with gave them a freedom to express their opinion. In this study, students were focused on generic structure, language features of descriptive text. Therefore, they could understand more about descriptive text and made their writing skill in descriptive text improved.

\section{CONCLUSION AND SUGGESTION}

\subsection{Conclusion}

After conducting the whole steps of this Classroom Action Research at SMP MULIA PRATAMA Medan, the writer draws some conclusions as follows:

1. Picture Word Inductive Model can improve students' writing skill. It was found out that the students' achievement of writing descriptive text improved from pretest to post-test after Picture Word Inductive Model was applied. The students' total mean score in pre-test is 35,6 , the formative test is 58,2 and post-test is 69,5 . Meanwhile, the students' score percentage who passed Mastery Minimum Criteria (Kriteria Ketuntasan Minimal (KKM)) from pre-test is $0(0 \%)$ students, formative test is $2(8 \%)$ students and post-test is $6(24 \%)$ students. It showed, that the percentage improvement of the students' mean score from pre- test to post-test is $24 \%$.

2. The process of teaching the students to improve the students' writing skill through PWIM has an effective result. Based on analysis of the questioner, the students' responses toward Picture Word Inductive Model were 9.2\% strongly disagree, $25.2 \%$ disagree, $38 \%$ agree and $27.6 \%$ strongly agree. From the result, it can be concluded that eventhough there are some students who disinterested with this model, their writing skill showed improvement.

\subsection{Suggestions}

The writer would like to give some suggestions for improving teaching descriptive text through Picture Word Inductive Model to be considered as follows:

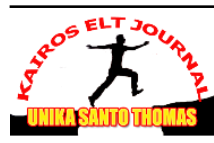


1. English teacher should use PWIM in teaching students' writing skill. To use this strategy the teacher must creative especially in skill of asking students. This strategy will enjoyable for the students because they have a freedom to give an opinion about their idea in their mind and also can push them to express it. This strategy was also suitable if use for improve students vocabularies.

2. Other researchers are recommended to enlarge the understanding about writing descriptive text using PWIM. This model is more suitable to improve vocabulary of students especially for new learners.

3. The students of SMP Mulia Pratama are suggested to be more motivated and serious in learning English. This stratregy was very useful to increase their writing include their vocabulary and they can be more mastering English. Finally, the writer realizes that this research must have some weaknesses and mistakes. Therefore, the writer would like to accept any constructive suggestions in order to make this research better.

\section{BIBLIOGRAPHY}

Burns, Anne. 2010. Doing Action Research in English Language Teaching. New York: Routlage

Calhoun Emily. F. 1999. Teaching Beginning Reading and Writing with the Picture Word Inductive Model. Alexandria: Association for Supervision and Curriculum Development.

Carroll, Joy Amstrong et al. 2001. Writing and Grammar. New Jersey : Precentice Hall.

Copeland, Matt. 2011. Writing in Various Settings. Kansas: KSDE Writing Consultant.

Gerrot, Linda and Peter Wignell. 1994. Making Sense of Functional Grammar. Sydney: Gerd Stabler.

Harmer, Jeremy. 2002. The Practice of English Language. London: Longman. 2004. How to Teach Writing. London: Longman.

Heaton, John Brian. 1988. Writing English Language Test. London: Longman.

Hyland, Ken. 2004. Genre and Second Language Writing. London : The University of Michigan Press

Kane, Thomas S. 2000. Essential Guide Writing. New York: Berkley Books

Lina, Sofia Andriani. 2015. The Use of PWIM Strategy to Improve Students' Writing Skill of Recount Text at Junior High School. Unpolished Sarjana's Thesis, English Department of Training and Education Faculty: UNNES 
Weigle, Sara Cushing. 2002. Assessing Writing. Cambridge :Cambridge University Press.

Wong, Bernice L. 2004. Learning about Learning Disabilities. Sacramento: Elseverer Academic Press.

Zuraida, Kartika et al. 2012. Improving Student's Writing Descriptive Text by Using PWIM. Jurnal Pendidikan dan Pembelajaran, 2(5), 8-10. 